\title{
Commentary
}

\section{Prophets without Honor: Peripheral Actors in Kenyan Journalism}

\author{
j. Siguru Wahutu ${ }^{1,2}$ \\ ${ }^{1}$ Department of Media, Culture, and Communication, New York University, New York, NY 10003, USA; \\ E-Mail: jswahutu@nyu.edu \\ 2 Berkman Klein Center for Internet and Society, Harvard University, Cambridge, MA 02138, USA
}

Submitted: 10 October 2019 | Accepted: 11 October 2019 | Published: 17 December 2019

\begin{abstract}
In sub-Sahara Africa, periphery contributors exist in a liminal space. They are at once valorized and treated with suspicion by the local journalism and political fields. Valorization occurs when they engage with, and challenge, journalism from the global north, and the opposite occurs when they do the same for the local fields. Focusing on the former and not the latter is a disservice to the complicated and nuanced relationship these actors have with the journalism field and perpetuates a mythologized and romanticized narrative about the redemptive qualities of online platforms.
\end{abstract}

\section{Keywords}

Africa; Kenya; journalism; social media

\section{Issue}

This commentary is part of the issue "Peripheral Actors in Journalism: Agents of Change in Journalism Culture and Practice" edited by Avery E. Holton (University of Utah, USA), Valerie Belair-Gagnon (University of Minnesota-Twin Cities, USA), and Oscar Westlund (Oslo Metropolitan University, Norway / Volda University College, Norway / University of Gothenburg, Sweden).

(C) 2019 by the author; licensee Cogitatio (Lisbon, Portugal). This article is licensed under a Creative Commons Attribution 4.0 International License (CC BY).

\section{Introduction}

This thematic issue brings together scholars that focus on peripheral actors in journalism fields whose presence has expanded with the advent of social and mobile media platforms. These actors have played a vital role in reshaping the boundaries of the global media field. Yet what often counts as the global media field mainly constitutes the global north and much less often the global south. Concomitantly, the promise and optimism that captured global north scholars led to valorizing these actors as harbingers of change. Such optimism has spread into the scholarly understandings of how these actors operate within Africa, specifically those that are within the social media universe. We keep hearing about networked Kenyans and how they are positively influencing how the global journalism field (meaning fields from the global north) cover their country. Nevertheless, there is little to no research about how these actors interact with their national journalism field. Focusing on the external, and not the internal, is a disservice to the complicated and nuanced relationship that these actors have with the journalism field, while also perpetuating the mythologized and romanticized narrative about the redemptive qualities of online networks.

We know very little about how the journalism field works in African countries (Brisset-Foucault, 2009; Wahutu, 2017). Scholarship tends to approach Africa with pre-packaged solutions for problems they imagine journalism fields in African countries have. We know a lot about how to solve these pre-constructed problems rather than what these fields do (McIntyre \& Sobel, 2018; Wahutu, 2018). Perhaps as a result of how little we know about African journalism fields, we have seen this same myopia seep into the discourse about 'fake news' in Africa, where theories and arguments developed in the global north are transposed onto African fields (see Wahutu, 2019a). While we are starting to see purposeful attempts to remedy this by conducting studies across multiple countries (see Wasserman \& Madrid-Morales, 2019) and across multiple fields (Nothias \& Cheruiyot, 2019; Nyabola, 2018a), there is space for more of this kind of work. Furthermore, there are very few scholarly outputs on how peripheral actors interact with na- 
tional journalism fields in Africa (Atton \& Mabweazara, 2011; Mabweazara, 2011a, 2011b; Mutsvairo, 2016; Nyabola, 2018a).

\section{The Virtual Town Square}

Building on this literature, this commentary focuses on two understudied types of actors in Kenya: 1) technologists in the news; and 2) networked Kenyans in the "virtual town square." The first are peripheral actors such as web analytics managers, developers, and webmasters who play a marginal role in the news construction process by the national journalism field. This group of actors has been reluctantly accepted into the fold by only one news organization, a radio station-this in a country with more than 100 radio stations. That being said, this radio station is considered, and is happy to label itself, as catering to primarily affluent and affluent-adjacent audience members. Audiences of this radio station are more likely to know what is happening in New York or Miami than in a Kenyan town on the border with Somalia. Presenters speak in a variety of American and British tinged accents, and the focus is on news and information geared to those enmeshed in a conspicuous consumption approach to life. Nonetheless, these peripheral actors find themselves firmly ensconced within the journalism field in Kenya by their explicit connection to this one radio station.

The radio station has been at the forefront in including peripheral actors in the construction of news. However, even within this space, the organization has divided its actual physical space into two distinct zones, each with distinct cultures: One space, referred to as the "newsroom" internally, is staffed by the traditional news actors with traditional roles, while the other, referred to as "digital," is where peripheral actors are located. Actors in the "digital" half refer to the content they produce as "soft news" or "features." It is at this radio that the notion of tracking what readers read using analytics has become semi-embedded into the construction process, becoming part of the encoding structure of the organization (Hall, 1993). The ability for this station to carve out a niche and focus solely on it means that they are keen on not only finding out who their audience is, but also when and how they consume the news. What is perhaps interesting in this radio station is that the webmaster had greater access to the content published by the radio station compared to an editor who has access to stories only in their beat (Wamunyu, 2017).

The inclusion of peripheral actors in the process is less about expanding the field and more about the organization targeting a particular segment of the audience. The radio is not interested in being a "mass medium" in the traditional sense, and it prides itself in eschewing the "mass" approach and targeting those higher up or climbing up the socio-economic ladder. The IT head alluded to this by indicating that their readers often visited their pages during weekday working hours, indicating that their audience was in the office where they had stable internet connectivity (Wamunyu \& Wahutu, 2019). Thus, the acceptance of webmasters and IT heads into the organization is not because online news consumption is typical in Kenya; rather, it is to help in ensuring that this subsection of the population is sufficiently tracked and catered for.

The second group of peripheral actors exists in what some call a virtual town square where members gather around salient issues, as constructed by hashtags, memes, trends, and politics (Kaigwa, 2017; Nyabola, 2018a, 2018b). We can think of this square as Russian nesting dolls, where a one virtual town square is likely to contain several more within it. Thus, the borders of the square can expand and contract while also being cross-cutting. It is in this square that we find actors such as bloggers and micro-bloggers (i.e., social media users). However, it is essential to point out that it is primarily relatively economically stable Kenyans that populate this town square. In the country affectionately referred to as the 'silicon savannah,' entry into the town square is limited to a select few. Ergo social media platforms are relatively niche products (Nyabola, 2018a, p. 101). It is therefore vital to remember that those that engage with the political or media fields, from within the square, represent a small minority in comparison to the population; they are a subsection of a subsection.

Indeed, few Kenyans have the technological knowhow, the right technology, and access to be considered 'contributors' in any meaningful way. This is not to say that Kenyans are not technologically savvy, but rather that we should always be careful not to exaggerate the level of engagement with platforms. To become a denizen of this square requires a level of economic capital. Except for WhatsApp, most other platforms require an exorbitant amount of data to be active, which is not cheap. Thus, despite the much-heralded strength of peripheral actors from the Kenyan virtual town square, Nyabola (2018a) continues to remind us that existence in this square is limited to a chosen few. The minimum requirements for the entry are having a good internet connection, enough disposable income to purchase this internet-whether at home or on your mobile phoneand having the appropriate technology. These requirements, which act as a visa for entry, remain inaccessible to a vast majority of Kenyans.

\section{Valorized or Marginalized Peripheral Actors?}

Denizens of the square are valorized (quite rightly often) for their contributions to and engagement with fields in the global north, even by the national journalism and political fields. However, we must be cognizant that they can be vilified and marginalized within their own nations. Even as they are hailed as paragons of engagement with the global north, their engagement with the national journalism field invites nothing but suspicion (see Wamunyu, 2017; Wamunyu \& Wahutu, 2019). This is in addition to the State clamping down on these ac- 
tors by relying on superfluous notions of national security (Gyuracz, 2016; Muraya, 2019; Osée, 2019). The level of cognitive dissonance from the simultaneous valorization and mistreatment by the political and journalism fields is as disconcerting to watch as it is to think through. While hailed as exemplary in their engagement with foreign news organizations, they find themselves not only derided, but their rights are abrogated. This group of actors are essentially prophets without honor in their own home, existing in liminality (see Said, 1989).

One group of actors that captures this bifurcation of treatment is Kenyans on Twitter (\#KOT); often hailed by both the State and the national journalism field as 'defenders' of Kenya's image internationally. \#KOT entered the world's conscience with the hashtag \#SomeoneTellCNN in 2012 in a pushback against CNN's framing of a grenade attack Kenyans viewed as exaggerating the scale of the violence. As Nothias and Cheruiyot (2019) found, David Mckenzie, who was credited with the story, would apologize soon after the hashtag appeared "among global trending topic" (p. 138). \#SomeoneTellCNN resurfaced in 2013 when CNN's Nima Elbagir covered a 'militia group' in Rift Valley, boldly, and woefully wrongly, predicting that violence would ensue during that election period. It showed up again in 2015 in a pushback against CNN's framing of Kenya as a 'terror hotbed' two days before the arrival of United States President Barack Obama.

Within Kenya, \#KOT is at the confluence of an informational moral panic, and a State that is increasingly intent on holding onto its paternalistic role as the informational gatekeeper. Thus, actors hailed as necessary when engaging with the global north find themselves treated with the suspicion of engaging in dis/misinformation in Kenya (Wamunyu \& Wahutu, 2019). Despite such distrust, at least once a week, daily and weekly newspapers have a section for tweets and comments from other platforms (Kaigwa, 2017, p. 193). Television and radio shows routinely solicit tweets from audiences. Indeed, a major television station created a show called The Trend, which promotes itself as a show focused on things that have 'trended' throughout the week and bringing them to the television audiences.

\section{Bringing Back the Global South in Peripheral Actors Studies}

How do we explain the disjuncture in how the political and journalism fields treat \#KOT? One reason may be that when peripheral actors tangle with the global north, they espouse and allow for commercial nationalism (see Nothias \& Cheruiyot, 2019; Tuwei \& Tully, 2017). When these actors reaffirm the amorphous notion of 'Kenyanness' - driving a narrative of an engaged and modern citizenry that is highly networked and acting as watchdogs against the sullying of Kenya's international image-they are welcomed into the fold. Subsequently, the journalism field views the square as a space that al- lows them to signal-albeit superficially and clumsilyengagement rather than as actors that contribute to the field's primary aim of knowledge construction. It is when actors turn their gaze inwards towards the cozy relationship between the journalism and political fields, or push for the national journalism field to be more responsible in its coverage, or point to the State's suppression of freedoms, that they are faced with suspicion and derision. It is at this stage that we can see a circling of the wagons by the journalism field. The field relies on journalistic norms as both a shield to deny actors entry but also a sword to push them back.

\section{Peripheral Actors and Field Boundaries}

Actors are not changing the boundaries of the journalism field. The Kenyan networked society did not necessarily move into "some sort of middle age" (Usher \& Carlson, 2018, p. 107), where it is part of the taken for granted communication motif. We have a long way to go in understanding and appreciating the political economy within which these actors are immersed. One factor to consider would be why not more than one radio station-or perhaps even why no newspaper-has actively worked to inculcate peripheral actors in the construction process. A possible reason is that although scholarship keeps on praising Kenya on the accessibility of the internet, the journalism field recognizes that access should not be conflated with actually going online. There is a realization within the journalism field that very few people consume their news online because it is an expensive endeavor. Moreover, assuming online news consumption presupposes not only that the internet connection will be stable enough, but also that the consumer can comfortably read English, a colonial vestige. As a result of internet instability and high price, most Kenyans that consume their news online will do it while they are in their offices. The logic being that if it is expensive to have internet at home, then one is better off using the office internet, a fact not unique to Kenya.

Even taking into account that Kenya is one of the global leaders in internet usage on mobile phones, there is the undeniable statistic that out of a country of 51.58 million people, only 13 million are active internet users (Namunwa, 2019). One of the critical factors in this paltry number is the high costs of data. With this in mind, many organizations within the field may feel that it is not financially feasible to bring in peripheral actors in the news construction process. In an interview conducted for a separate project, a sub-editor of one of Kenya's leading newspapers (one of the largest media conglomerates on the continent outside of South Africa) recounted their exasperation with their organization's unwillingness to not only be at the forefront of trying to make their online face user-friendly but also that they had refused to bring in people with the expertise to use web analytics to understand their papers' audiences better (Personal communication, 2015). 
Therefore, while we may be familiar with some facet of how those in the town square interact with organizations from the global north, we know very little of the negotiations of class, race, and gender that allow/facilitate this interaction. This suggests that we know even less about how these very factors play out within the national boundaries. For example, seeing as most of the tweets from Kenya originate from Nairobi, the capital city, how representative is the "K" in \#KOT? Especially when we consider the subset of Kenyans that have not only access to electricity, but also disposable income, access to the internet, appropriate technology to access the internet, and have a social media account. This is even more complicated considering Twitter's popularity in Kenya lagging behind WhatsApp, Facebook, YouTube, Instagram, and LinkedIn, respectively (see Nyabola, 2018a, p. 83).

Furthermore, while social media has grown across the continent, so too has the State's adeptness in manipulating discourse in the town square; not to mention the State's willingness to consider internet shutdowns. From the State's perspective, these actors are only useful when their gaze and ire are trained towards the global north. When they are outward-facing and engaged in performing patriotic citizenship, the State has been more than happy to elevate denizens of the town square. It is these interactions that appear to have so enamored scholarship that focuses on the redemptive qualities brought about by the introduction of various social media platforms. Once denizens focus on issues within the country, the State has tirelessly worked to not only suppress any form of collective action but prosecuted those it deemed too dangerous. The State has been known to deploy an army of bots to drown out any form of critique against it that threatens to go somewhat viral.

Denizens turning the gaze inwards have also seen the invocation of national security and charges of promoting terror by the State. This charge has seen a steady rise in use by States on the continent in the post 9/11 world we are immersed in currently. In Kenya, we have seen the arrests of bloggers like Robert Alai and Cyprian Nyakundi on charges of publishing 'alarming' information. The irony is that Mr. Alai was awarded a State commendation in 2017 but has been arrested severally since. In 2016 alone, the Bloggers Association of Kenya claimed that 60 of its members were arrested for remarks made on social media (Moseti, 2016). What we see is a State bearing no compunction, when not only arresting bloggers and micro-bloggers but also proposing laws that seek to curtail their rights and freedoms specifically. Even in 2019, the State in Kenya is trying to amend an already problematic Information and Communications Act. One of the more controversial amendments is the attempt to institute a licensing fee to "establish a social media platform" where social media platform is defined to include "blogging, social networking, document and data sharing repositories, [and] social media applications" (Parliament of Kenya, 2019). The bill proposes that when one creates a group on a platform, such as
WhatsApp or ostensibly Facebook, they are supposed to inform Facebook that the group was formed. Failure to comply with this provision would lead to the administrator paying a fine of almost $\$ 2000$ or being jailed for at most a year. Thus, the town square finds itself in a similar position to where the national journalism field was in the mid-aughts, with the State working towards constricting the space for expression while the rest of the world hails the facile strides the community has made internationally.

\section{Conclusion}

Taking the geographic boundedness of Africa seriously requires us to acknowledge that we know very little about how peripheral actors affect the boundaries of the journalism field within the continent. This is especially poignant when we consider that journalism fields in crucial African markets are bifurcated (Mare, 2013; Wahutu, 2019b); perhaps these peripheral actors have made inroads in both subfields. It is almost as though scholarship in this arena has been so eager to move away from Afropessimism discourse (Nothias, 2014) towards a blinding afro-optimist one. The result of this is a fundamental miscarriage of scholarly justice with regards to the nuances of the contributions by African peripheral actors to African journalism fields.

\section{Acknowledgments}

I would like to thank Valerie Belaire-Gagnon, Avery Holton, and Oscar Westlund for the wonderful feedback on a prior version of this commentary. I would also like to thank Kikelomo C. Aluko for helping me think through my arguments and how to best present them.

\section{Conflict of Interests}

The author declares no conflict of interests.

\section{References}

Atton, C., \& Mabweazara, H. (2011). New media and journalism practice in Africa: An agenda for research. Journalism, 12(6), 667-673. https://doi.org/ $10.1177 / 1464884911405467$

Brisset-Foucault, F. (2009). Quel 'autre journalisme' en Afrique? La production de modèles médiatiques africains au forum social mondial de Nairobi [What 'other journalism' in Africa? The production of African media models at the Nairobi World Social Forum]. Réseaux, 157/158(5), 125-156. https://doi. org/10.3917/res.157.0125

Gyuracz, V. (2016). Investigative journalism and human trafficking in West Africa. Africa Spectrum, 51(3), 77-92. https://doi.org/10.1177/0002039716051003 04

Hall, S. (1993). Encoding and decoding in the televi- 
sion discourse. In S. During (Ed.), The cultural studies reader, (Vol. 2, pp. 508-517). London: Routledge.

Kaigwa, M. (2017). From cyber café to smartphone: Kenya's social media lens zooms in on the country and out to the world. In B. Ndemo \& T. Weiss (Eds.), Digital Kenya: An entrepreneurial revolution in the making (pp. 187-222). https://doi.org/10.1057/9781-137-57878-5_7

Mabweazara, H. (2011a). Between the newsroom and the pub: The mobile phone in the dynamics of everyday mainstream journalism practice in Zimbabwe. Journalism, 12(6), 692-707.

Mabweazara, H. (2011b). The internet in the print newsroom: Trends, practices, and emerging cultures in Zimbabwe. In D. Domingo \& C. Peterson (Eds.), Making online news, volume 2: Newsroom ethnographies in the second decade of Internet journalism (pp. 57-69). New York, NY: Peter Lang.

Mare, A. (2013). A complicated but symbiotic affair: The relationship between mainstream media and social media in the coverage of social protests in southern Africa. Ecquid Novi: African Journalism Studies, 34(1), 83-98. https://doi.org/10.1080/02560054. 2013.767426

McIntyre, K., \& Sobel, M. (2018). Reconstructing Rwanda: How Rwandan reporters use constructive journalism to promote peace. Journalism Studies, 19(14), 2126-2147. https://doi.org/10.1080/ 1461670X.2017.1326834

Moseti, B. (2016, November 30). 60 bloggers arrested in Kenya this year. The Daily Nation.

Muraya, J. (2019, June 18). Blogger Robert Alai arrested for posting gory photos. Capital News.

Mutsvairo, B. (2016). Digital activism in the social media era. Cham: Palgrave MacMillan.

Namunwa, K. (2019, March 11). Kenya leads Africa in smartphone usage. Business Today. Retrieved from https://businesstoday.co.ke/kenya-leads-africasmartphone-usage

Nothias, T. (2014). 'Rising,' 'hopeful,' 'new': Visualizing Africa in the age of globalization. Visual Communication, 13(3), 323-339. https://doi.org/10.1177/ 1470357214530063

Nothias, T., \& Cheruiyot, D. (2019). A "hotbed" of digital empowerment? Media criticism in Kenya between playful engagement and co-option. International Association for Media and Communication Research, 13, 136-159.

Nyabola, N. (2018a). Digital democracy, analogue politics: How the internet era is transforming politics in Kenya. London: Zed Books.

Nyabola, N. (2018b, March 22). Politics in the digital age:
Cambridge Analytica in Kenya. Al Jazeera. Retrieved from https://www.aljazeera.com/indepth/opinion/ politics-digital-age-cambridge-analytica-kenya180322123648852.html

Osée, K. (2019). Difficile émergence d'un journalisme objectif en Afrique: Origine du drame et pistes de solution [Difficult emergence of objective journalism in Africa: Origin of the drama and possible solutions]. Communication, 36(1). https://doi.org/10. 4000/communication.9827

Parliament of Kenya. (2019). The Kenya information and communications (amendment) bill. Nairobi: Parliament of Kenya.

Said, W. (1989). Representing the colonised: Anthropology's interlocutors. Critical Inquiry, 15(2), 205-225.

Tuwei, D., \& Tully, M. (2017). Producing communities and commodities: Safaricom and commercial nationalism in Kenya. Global Media and Communication, 13(1), 21-39. https://doi.org/10.1177/ 1742766517694471

Usher, N., \& Carlson, M. (2018). The midlife crisis of the network society. Media and Communication, 6(4), 107. https://doi.org/10.17645/mac.v6i4.1751

Wahutu, j. S. (2017). The representations of Africa in African media: The case of the Darfur violence. African Affairs, 117(466), 44-61. https://doi.org/10. 1093/afraf/adx039

Wahutu, j. S. (2018). The politics of representation: Wire agencies and local news organizations in the coverage of Darfur. Sociological Forum, 33(2), 465-481. https://doi.org/10.1111/socf.12417

Wahutu, j. S. (2019a). Fake news and journalistic "rules of the game." African Journalism Studies. https://doi. org/10.1080/23743670.2019.1628794

Wahutu, j. S. (2019b). "We have failed as a continent": Covering an African atrocity for an African audience. In A. Thompson (Ed.), Media and mass atrocity: The Rwanda genocide and beyond (pp. 237-252). Montreal: McGill-Queen's Press.

Wamunyu, W. (2017). New actors in journalistic practice: The case of a Kenyan radio station. Journal of Language, Technology, \& Entrepreneurship in Africa, 8(2), 26-35.

Wamunyu, W., \& Wahutu, j. S. (2019). Old habits, new realities: Digital newsrooms in Kenyan commercial media houses. African Journalism Studies, 40(1), 36-52. https://doi.org/10.1080/23743670.2019.1583583

Wasserman, H., \& Madrid-Morales, D. (2019). An exploratory study of "fake news" and media trust in Kenya, Nigeria and South Africa. African Journalism Studies, 40(1), 107-123. https://doi.org/10. $1080 / 23743670.2019 .1627230$ 


\section{About the Author}

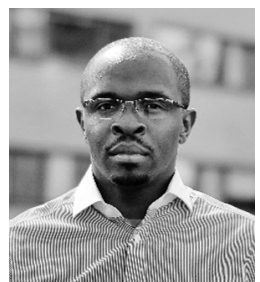

j. Siguru Wahutu (PhD, University of Minnesota) is an Assistant Professor in New York University's Department of Media, Culture, and Communication, and a Faculty Associate at the Berkman Klein Center of Internet and Society at Harvard University. His primary research is on the sociology of media, with an emphasis on genocide, mass violence, and ethnicity in sub-Saharan Africa. He has written about global media patterns in covering genocide in Africa, on ethnicity, land, and politics in Kenya, and on the Kenyan media's experimentation with social media platforms. Wahutu's research has appeared in African Affairs, African Journalism Studies, Sociological Forum, Media, Culture, and Society, and Global Media and Communication. 